\title{
Segregation of Leptatherum from Microstegium (Andropogoneae, Poaceae) confirmed by Internal Transcribed Spacer DNA sequences
}

\author{
C.-H. Chen ${ }^{1,3}$, J.F. Veldkamp², C.-S. Kuoh ${ }^{3}$, C.-C. Tsai ${ }^{4,5}$, Y.-C. Chiang ${ }^{5}$
}

Key words

Andropogoneae

ITS

Leptatherum

Microstegium

phylogeny

Poaceae

taxonomy

\begin{abstract}
Phylogenetic analyses of Microstegium (Andropogoneae, Poaceae) and some other Andropogoneae species were conducted inferred from the ITS/5.8S sequences. As a result of this study, Microstegium is polyphyletic. There are two rather distant monophyletic clades, one with Microstegium nudum (type of Leptatherum), M. japonicum and $M$. somae, the other one with M. ciliatum, M. fauriei, M. geniculatum and M. vimineum (type of Microstegium). Therefore we feel justified to reinstate the genus Leptatherum and three new combinations, Leptatherum boreale, L. nudum and L. somae, are proposed.
\end{abstract}

Published on 30 October 2009

\section{INTRODUCTION}

The genus Microstegium Nees belongs to the tribe Andropogoneae of the family Poaceae and contains about 25 species. They are widely distributed in the tropical and subtropical Old World (Clayton \& Renvoize 1986, Koyama 1987, Watson \& Dallwitz 1992, Hsu 2000). They are creeping or rambling annual or perennial plants with broadly linear to lanceolate leafblades, inflorescences of 1-many subdigitate racemes with a fragile rachis; internodes filiform to clavate or inflated; sessile spikelet: lower glume dorsally with a deep grove or a broadly concave median channel, the margins sharply inflexed and usually keeled; upper glume often shortly awned; lower floret well developed, reduced to a palea or absent; upper lemma linear to cordate and usually with long awns, usually accompanied by a small palea; stamens 3 , rarely 2 ; pedicelled spikelet resembling the sessile one, occasionally slightly smaller and male (Clayton \& Renvoize 1986).

The genus was first distinguished by Trinius (1832) as Pollinia Trin., a name previously used by Sprengel (1815) for what now is Chrysopogon Trin., so it is a later homonym and illegitimate. Microstegium was erected by Nees (1836) with as the only species and thus the type, $M$. willdenovianum Nees, now to be called $M$. vimineum (Trin.) A. Camus. The original specimen, Wallich 8838 in B is lost, but there are duplicates in BM, CAL, E, G, K (microfiche IDC 7394), L and P.

Nees (1841a, b) described another genus, Leptatherum Nees, with as type $L$. royleanum Nees, now $M$. nudum (Trin.) A. Camus. In most subsequent publications this has been regarded as a

\footnotetext{
${ }^{1}$ Endemic Species Research Institute, \#1, Ming-Sheng E. Rd., Chi-Chi, Nantou, Taiwan; corresponding author e-mail: chchen@tesri.gov.tw.

2 National Herbarium of the Netherlands, Leiden University branch, P.O. Box 9514, 2300 RA Leiden, The Netherlands.

${ }^{3}$ Department of Life Science, National Cheng-Kung University, \#1, Ta-Hsueh Road, Tainan City, Taiwan.

4 Taohsiung District Agricultural Improvement Station, Pingtung 900, Taiwan; e-mail: tsaicc@mail.kdais.gov.tw

${ }_{5}^{5}$ Department of Life Sciences, Pingtung University of Science and Technology, Pingtung, Taiwan 912; e-mail: yuchung@mail.npust.edu.tw
}

synonym of Microstegium. However, Tzvelev (1966) considered it to be a distinct section of Microstegium, based on the slender and hairless racemes, abruptly acute glume apex and concave dorsal face of the lower glumes. He included $M$. nudum and M. japonicum (Miq.) Koidz. (as a subspecies) in it. In these species the stamens are 2 per floret, while they are usually 3 in the species of Microstegium, only M. tenue (Trin.) Hosok. has 1.

Hayata (1918) created the genus Polliniopsis Hayata for $P$. somae Hayata (usually and erroneously written as 'somai'). He regarded it as distinct because of the binate spikelets which are both pedicelled, and in the 2-aristate lower glume, and an upper glume, lower lemma and upper lemma each with a long awn. So a single spikelet has 3 awns. There are 2 stamens per floret. Ohwi (1942) regarded it as belonging to Microstegium, and made the combination $M$. somae (Hayata) Ohwi for it. Koyama (1987) went even further and regarded it as a subspecies of M. japonicum, subsp. somae (Hayata) T.Koyama.

A generic distinction between Microstegium and Leptatherum was indicated by Spangler (Spangler et al. 1999, Spangler 2000 ) in a survey of the phylogeny of chloroplast gene $n d h F$ sequences of Andropogoneae. Here M. vinimeum and M. nudum were not in one monophyletic clade but were separated far apart in the cladogram. These two species are the types of Microstegium and Leptatherum, respectively. A weakness in their strict consensus tree of $n d h F$ gene is that most internal nodes have only relatively low support measures (Spangler et al. 1999). However, in addition to $n d h F$ gene, two other nuclear genes, waxy (Mason-Gamer et al. 1998) and phytochrome B (Mathews et al. 2002), show the same pattern of short internal branch lengths, suggesting a similar pattern of evolution. This repeated pattern across genes and genomes made Spangler et al. confident that their topology of $n d h \mathrm{~F}$ gene tree for Andropogoneae is the correct one rather than one reflecting coincidental convergence (Spangler et al. 1999). In another word, the genus Microstegium is polyphyletic (Mathews et al. 2002). Though we knew the distinction between the M. nudum group and the other species of Microstegium, this result was quite astonishing. We even suspected that the author(s) might have misidentified their materials. 
In this study, we wanted to elucidate the phylogeny of the M. nudum group and some representative species of Microstegium and to see if we could repeat or refute Spangler et al.'s observation. Since the internal transcribed spacer (ITS) region of the nuclear ribosomal cistron (18S-5.8S-26S) has been used for plant molecular systematic research at the species level (AIvarez \& Wendel 2003) with a good effectiveness of species-level discrimination and technical ease, a large body of sequence data already exists in the GenBank for this region (Kress et al. 2005). In addition, it has been suggested as a potential plant barcode locus (Stoeckle 2003, Kress et al. 2005). Therefore we chose it as a marker to achieve the above objectives.

\section{MATERIAL AND METHODS}

\section{Taxa sampling}

A total of 23 accessions of ITS sequences of seven Microstegium species were processed. Seven were of $M$. ciliatum (Trin.) A. Camus, two of $M$. vimineum, two of $M$. fauriei (Hayata) Honda, one of M. geniculatum (Hayata) Honda, three of M. nudum, four of $M$. somae and four of $M$. japonicum (see Table 1 for details). All vouchers were deposited in the herbaria of the Endemic Species Research Institute (TAIE) and the National Museum of Natural Science (TNM), Taiwan.

\section{Molecular methods}

Leaves dried in silica gel or taken from herbarium specimens were frozen with liquid nitrogen and crushed using a mortar and pestle. The total DNA was extracted using a modified cetyltrimethyl-ammonium bromide (CTAB) extraction procedure (Murray \& Thompson 1980).

The ITS region, which includes the ITS1, 5.8S rDNA and ITS2, was amplified by PCR with primers we designed based on the 26S rRNA gene and 18S rRNA gene of some other grasses. The sequence of forward primer, IT-11:5'-TCG TAA CAA GGT TTC CGT AGG T-3', is located at the 3' end of 18S rRNA gene, and the reverse one, IT-8:5'-GTAAGT TTC TTC TCC GCT-3', at the beginning sequence of $26 \mathrm{~S}$ rRNA gene.

The protocols for the PCR were as follows: we used a 50 $\mu \mathrm{l}$ mixture containing $40 \mathrm{mM}$ Tricine- $\mathrm{KOH}(\mathrm{pH} 8.7), 15 \mathrm{mM}$

Table 1 Information of the 23 Microstegium samples used in this study.

\begin{tabular}{|c|c|c|c|c|}
\hline Taxa & $\begin{array}{l}\text { Sample } \\
\text { number }\end{array}$ & $\begin{array}{l}\text { Voucher } \\
\text { information }\end{array}$ & $\begin{array}{l}\text { Deposit } \\
\text { herbarium }\end{array}$ & $\begin{array}{l}\text { GENBANK } \\
\text { accession } \\
\text { number }\end{array}$ \\
\hline \multicolumn{5}{|c|}{ Microstegium vimineum group } \\
\hline \multirow[t]{7}{*}{ M. ciliatum } & $\mathrm{S} 22$ & Wu 17-033 & TNM & EU489066 \\
\hline & $\mathrm{S} 28$ & S90933 & TNM & EU489068 \\
\hline & S42 & Huang 62 & TNM & EU489069 \\
\hline & S46 & S90921 & TNM & EU489070 \\
\hline & W39 & Chen 5639 & TAIE & EU489077 \\
\hline & W53 & Chen 5737 & TAIE & EU489086 \\
\hline & W56 & Chen 5741 & TAIE & EU489087 \\
\hline \multirow[t]{2}{*}{ M. fauriei } & W42 & Chen 5642 & TAIE & EU489079 \\
\hline & W60 & Chen 5799 & TAIE & EU489088 \\
\hline M. geniculatum & W61 & Chen 5802 & TAIE & EU489071 \\
\hline \multirow[t]{2}{*}{ M. vimineum } & W44 & Chen 5644 & TAIE & EU489080 \\
\hline & W50 & Chen 5628 & TAIE & EU489083 \\
\hline \multicolumn{5}{|c|}{ Microstegium nudum group } \\
\hline \multirow[t]{4}{*}{ M. japonicum } & W45 & Chen 5623 & TAIE & EU489081 \\
\hline & W46 & Chen 5624 & TAIE & EU489082 \\
\hline & W52 & Chen 5630 & TAIE & EU489085 \\
\hline & W65 & Chen 5690 & TAIE & EU489076 \\
\hline \multirow[t]{3}{*}{ M. nudum } & $\mathrm{S} 24$ & Liu 890367 & TNM & EU489067 \\
\hline & W34 & Chen 5634 & TAIE & EU489073 \\
\hline & W40 & Chen 5640 & TAIE & EU489078 \\
\hline \multirow[t]{4}{*}{ M. somae } & W32 & Chen 5631 & TAIE & EU489072 \\
\hline & W35 & Chen 5635 & TAIE & EU489074 \\
\hline & W36 & Chen 5636 & TAIE & EU489075 \\
\hline & W51 & Chen 5629 & TAIE & EU489084 \\
\hline
\end{tabular}

$\mathrm{KOAc}, 3.5 \mathrm{mM} \mathrm{Mg}(\mathrm{OAc})_{2}, 3.75 \mu \mathrm{g} / \mathrm{ml} \mathrm{BSA}, 0.005 \%$ Tween $20,0.005 \%$ Nonidet-P40, four dNTPs (0.2 mM each), primers $(0.5 \mu \mathrm{M}$ each), 2.5 units of Advantage 2 DNA polymerase (Clontech), $10 \mathrm{ng}$ genomic DNA, and a $50 \mu$ volume of mineral oil. The PCR mixture for amplifying the ITS region included $10 \%$ dimethylsulfoxide (DMSO) to reduce problems related to the secondary structure and efficiency of PCR primer binding. Amplification reactions were completed in a dry-block with two-step thermal cycles (Biometra). In the first step, the mixture was incubated at $94{ }^{\circ} \mathrm{C}$ for $3 \mathrm{~min}$, then it underwent 10 cycles of denaturation at $94^{\circ} \mathrm{C}$ for $45 \mathrm{~s}$, annealing at $58^{\circ} \mathrm{C}$ for $45 \mathrm{~s}$, and extension at $72{ }^{\circ} \mathrm{C}$ for $1 \mathrm{~min}$. The second step was carried out by the following process: 30 cycles of denaturation at $94^{\circ} \mathrm{C}$ for $45 \mathrm{~s}$, annealing at $54{ }^{\circ} \mathrm{C}$ for $45 \mathrm{~s}$, and extension at $72{ }^{\circ} \mathrm{C}$ for $1 \mathrm{~min}$, with a final extension for $10 \mathrm{~min}$ at $72{ }^{\circ} \mathrm{C}$. These PCR products were detected by agarose gel electrophoresis $(1.0 \%$, $\mathrm{w} / \mathrm{v}$ in TBE), stained with $0.5 \mu \mathrm{g} / \mathrm{ml}$ ethidiumbromide, and finally photographed under UV light exposure.

These DNAs were directly sequenced following the method of dideoxy chain-termination using an ABI377 automated sequencer with the Ready Reaction Kit (PE Biosystems, California) of the BigDye ${ }^{\mathrm{TM}}$ Terminator Cycle Sequencing. Sequencing primers were the same as those used for PCR. Each sample was sequenced two or three times to confirm the sequences. These reactions were performed as recommended by the manufacturers.

\section{Sequence alignment and phylogenetic analysis}

In addition to the 23 accessions of Microstegium, the ITS sequences of 31 accessions of Andropogoneae and fifteen accessions of Paniceae were obtained from GenBank.

Alignment of obtained sequences was first aided by using the program Clustal W multiple alignment in BioEdit (Hall 1999), and adjusted manually. The aligned data matrix and tree files are available from the first author.

Phylogenetic trees were constructed using two methods, neighbour-joining (NJ) (Saitou \& Nei 1987) and maximum parsimony (MP) (Swofford et al. 1996). Both NJ and MP analyses were conducted using MEGA v4 (Tamura et al. 2007), and rooted by the Paniceae accessions. For the $\mathrm{NJ}$ analysis, a rooted tree was generated from the distance matrix calculated by the twoparameter method of Kimura (1980). The MP tree was obtained using the Close-Neighbour-Interchange algorithm (Nei \& Kumar 2000) with search level 3 (Felsenstein 1985, Nei \& Kumar 2000 ) in which the initial trees were obtained with the random addition of sequences (10 replicates). The strict consensus parsimonious tree was then constructed. Supporting levels for nodes in both analyses were assessed with a bootstrap analysis (Felsenstein 1985) using 1000 replicates.

\section{RESULTS}

The 23 new sequences produced in this study have been submitted to GenBank (see Table 1 for their accession numbers). The dataset had a total of $618 \mathrm{bp}$ of aligned ITS sequence for each taxon with 326 variable characters and 249 of those were parsimony informative $(40.3 \%$ of the total ITS sequence length). The MP analysis resulted in 33 most parsimonious trees (length $=761$ ), with consistency index $(\mathrm{Cl})$ of 0.442336 , and retention index $(\mathrm{RI})$ of 0.768485 , for parsimony informative sites. The percentage of replicate trees in which the associated taxa clustered together in the bootstrap test (1 000 replicates) are shown next to the branches.

The topologies of NJ tree and MP bootstrap consensus tree are as Fig. 1 and Fig. 2, respectively. In both trees, the species name and accession number of all the OTUs were given. 


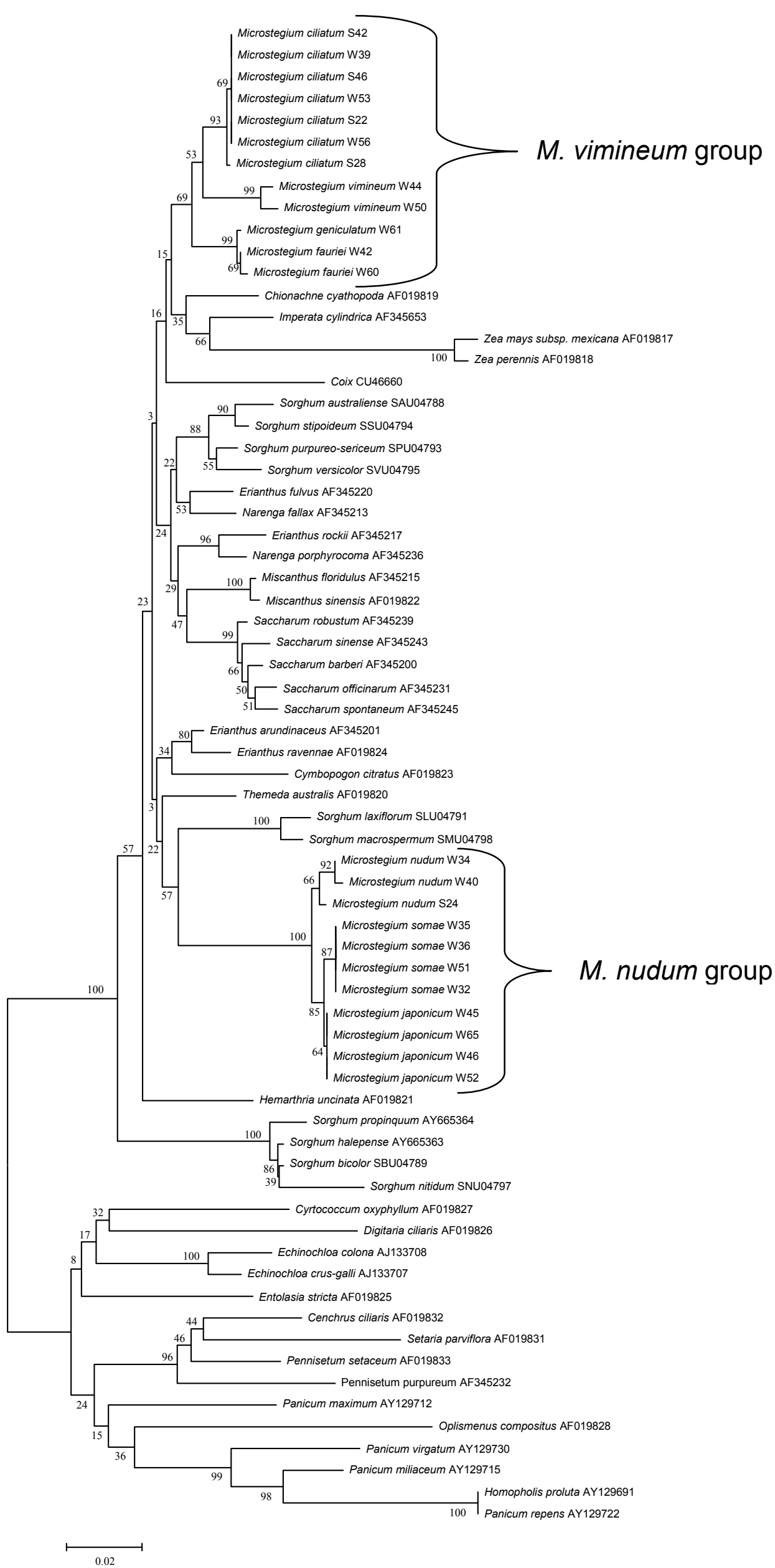

Fig. 1 Phylogenetic tree resulted from NJ analysis inferred from the ITS/5.8S sequences of Microstegium and some other Andropogoneae species. The percentage of replicate trees in which the associated taxa clustered together in the bootstrap test (1 000 replicates) are shown next to the branches. 


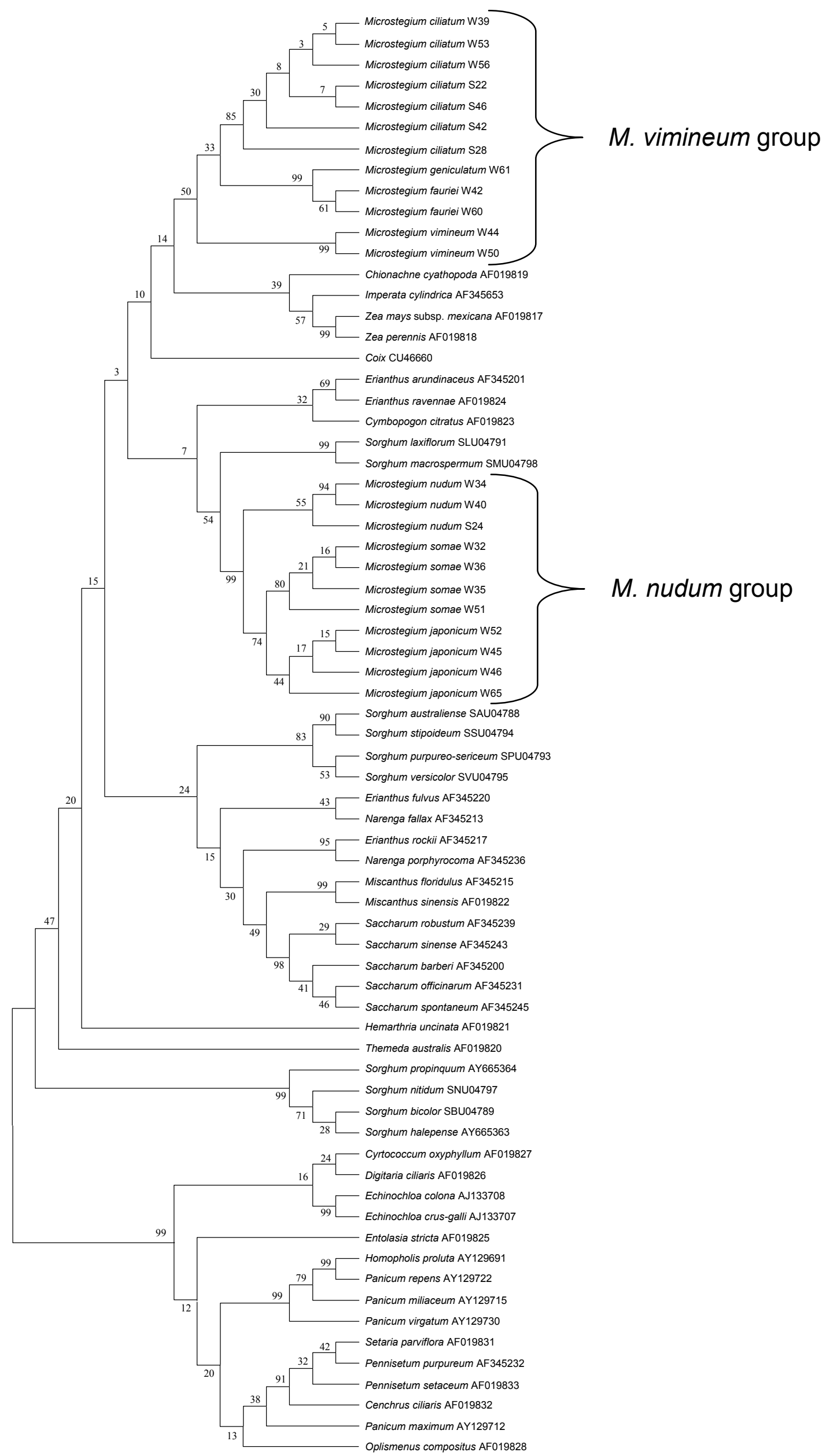

Fig. 2 Consensus parsimonious tree resulted from NJ analysis inferred from the ITS/5.8S sequences of Microstegium and some other Andropogoneae species. The percentage of replicate trees in which the associated taxa clustered together in the bootstrap test (1 000 replicates) are shown next to the branches. 
Though the topologies of two trees are not identical, they both demonstrate that the Microstegium are not in one monophyletic clade but are separated far apart in the cladogram. This result is in accordance with that of Spangler which was obtained from $n d h F$ sequences (Spangler et al. 1999, Spangler 2000). In both $\mathrm{NJ}$ and MP trees, the M. nudum group formed a monophyletic clade with very strong bootstrap support (100 \% in NJ tree and $99 \%$ in MP trees). The other species, including $M$. ciliatum, $M$. fauriei and $M$. geniculatum and $M$. vimineum (hereafter $M$. vimineum group), formed another monophyletic clade but with low bootstrap support (only $69 \%$ in NJ tree and $50 \%$ in MP trees). Besides, the phenomenon of relatively low bootstrap supports for most internal nodes in both our NJ and MP trees is similar to Spangler et al.'s result, too.

\section{DISCUSSION}

In our results, the NJ and MP analyses both support the results of Spangler et al. (1999) that $M$. vimineum is widely separated from $M$. nudum, although we also were unable to recover a reasonable level of support for the intervening nodes. Similar to Spangler et al.'s result of $n d h F$ gene (1999), our NJ and MP tree of ITS sequences have relatively low supports for most internal nodes. It is a problem to determine how the nodes are related to each other. Spangler et al.'s result and ours both indicate the level of molecular divergence within the tribe is low. However, at least, the clade of the M. nudum group are very well supported. This can correspond with Tzvelev's (1966) opinion that Leptatherum (incl. M. somae) can be distinguished from Microstegium at the infrageneric level.

All results obtained so far therefore indicate that Microstegium is non-monophyletic and consists of two separate clades. One of them is composed of the M. nudum group, the other of M. vimineum and allies. Although, in view of the low bootstrap supports, further confirmation is necessary, we think that our results in combination with those of Spangler (2000) and Mathews et al.'s (2002) opinion justify the reinstatement of Leptatherum as a distinct genus, necessitating three new combinations, Leptatherum boreale (Ohwi) C.-H. Chen, C.-S. Kuoh, Veldk., L. nudum (Trin.) C.-H. Chen, C.-S. Kuoh, Veldk. and L. somae (Hayata) C.-H. Chen, C.-S. Kuoh, Veldk.

\section{KEY TO THE SPECIES}

1. Ligule absent. Blades firm, base broadly rounded. Racemes drooping, rachis tenaceous. Sessile spikelets with a short pedicel, deciduous without the adjacent joint or pedicel of the pedicelled spikelet. - China, Taiwan, Japan, S. Korea

1. Ligule a glabrous membrane. Blades flaccid, base attenuate to slightly rounded. Racemes patent, rachis fragile. Sessile spikelets without a short pedicel, deciduous with the adjacent joint and pedicel of the pedicelled spikelet. - S Africa to Japan and New Guinea . . . . . . . . . . . . . 2. L. nudum

2. Upper glume muticous. Lower lemma oblong, muticous. - China (Anhui, Hubei, Hunan, Jiangsu, Jiangxi, Zhejiang), Japan, S. Korea . . . . . . . . . . . . . . . . . 1. L. boreale

2. Upper glume mucronate. Lower lemma lanceolate, awned. - China (Anhui, Fujian), Taiwan, Ryukyu Isl. . 3. L. somae

\section{Leptatherum boreale (Ohwi) C.-H. Chen, C.-S. Kuoh,} Veldk., comb. nov.

Microstegium boreale Ohwi, J. Jap. Bot. 12 (1936) 653. - Microstegium nudum (Trin.) A.Camus var. boreale (Ohwi) Ohwi (1937) 151. - Microstegium japonicum (Miq.) Koidz. var. boreale (Ohwi) Ohwi (1942) 156. - Type: Ohwi \& Tagawa 727 (holo KYO).
Pollinia japonica Miq. (1866a) 290; (1866b) 178. - [Pollinia japonica Miq. var. polystachya Franch. \& Sav. (1876) 190, nom. inval.]. — Microstegium japonicum (Miq.) Koidz. (1929) 394. - [Microstegium vimineum (Trin.) A.Camus var. polystachyum (Franch. \& Sav.) Ohwi (1942) 156, nom. inval.]. - [Pogonatherum glabratum (Brongn.) Roberty subvar. japonicum (Miq.) Roberty (1960) 388, nom. inval.]. - [Microstegium vimineum (Trin.) A.Camus forma polystachyum (Franch. \& Sav.) T.K.Koyama (1971) 65, nom. inval.]. - Microstegium nudum (Trin.) A.Camus subsp. japonicum (Miq.) Tzvelev (1976) 695. - Type: Keiske s.n. (holo L).

Microstegium nudum (Trin.) A.Camus var. shimidzui Honda (1930) 407. - Microstegium japonicum (Miq.) Koidz. forma shimidzui (Honda) Ohwi (1942) 156. - Type: Shimizu s.n. 1929 (holo TI).

Note - The combination Leptatherum japonicum (Miq.) cannot be made, as there already is the heterotypic $L$. japonicum Franch. \& Sav., a synonym of $L$. nudum, q.v. A line drawing plate of this species has been made by Chen \& Kuoh (2007).

\section{Leptatherum nudum (Trin.) C.-H. Chen, C.-S. Kuoh, Veldk.,} comb. nov.

Pollinia nuda Trin., Mém. Acad. Imp. Sci. St. Pétersbourg VI, Sci. Math. 2 (1832) 307. - [Pollinia nuda Trin. var. genuina Hack. (1889) 179, nom. inval.]. - Eulalia nuda (Trin.) Kuntze (1891) 775. - Microstegium nudum (Trin.) A.Camus (1921) 201. - [Pogonatherum glabratum (Brongn.) Roberty subvar. nudum (Trin.) Roberty (1960) 389, nom. inval.]. - Type: Wallich ex Hornemann in Herb. Trinius 56.1 (holo LE, drawing \& fragm., IDC microfiche BT-16/1; this probably is Wallich Cat. 8831, microfiche IDC 7394, photo in BRI, as this is the only collection of this species in the Wallich herbarium; iso $\mathrm{C}, \mathrm{CAL}, \mathrm{E}, \mathrm{K}, \mathrm{L}, \mathrm{P})$.

Leptatherum royleanum Nees (1841a) 93; (1841b) 220; cited by Steud. (1854) 409] as “Jard. Annal. vii: 220". - Type: Herb. Royle 219 (holo B, lost?; iso CGE?, LIV?, W).

Psilopogon capensis Hochst. (1846) 117. - Eulalia capensis (Hochst.) Hochst. ex Steud. (1854) 412. — Pollinia nuda Trin. var. capensis (Hochst.) Hack. (1889) 179. - Microstegium capense (Hochst.) A.Camus (1921) 201. - Type: C. Krauss 92 (holo HBG).

Leptatherum japonicum Franch. \& Sav. (1876) 190; (1878) 609. - Type: Savatier 1507, 2557 (syn P).

Pollinia arisanensis Hayata (1918) 74, t. 43. - Microstegium arisanense (Hayata) A.Camus (1921) 201. - Type: Faurie Dec. 1914 (holo TI).

Microstegium mayebaranum Honda (1930) 405. - Type: Mayebara 334, 335, 345, 346, Miyagi 394, Sakaguchi 10 (syn TI).

Note - A line drawing plate of this species has been made by Hsu (1975).

3. Leptatherum somae (Hayata) C.-H. Chen, C.-S. Kuoh, Veldk., comb. nov.

Microstegium somae (Hayata) Ohwi, Acta Phytotax. Geobot. 11 (1942) 155 - Polliniopsis somae Hayata (1918) 76. — [Ischaemum petiolare (Trin.) Hack. var. somae (Hayata) Roberty (1960) 346, nom. inval.]. - Microstegium japonicum (Miq.) Koidz. var. somae (Hayata) T.Koyama (1962) 238. - Microstegium japonicum (Miq.) Koidz. subsp. somae (Hayata) T.Koyama (1987) 427, 516. - Type: Soma s.n. 1914 (holo TI).

Note - A line drawing plate of this species has been made by Hsu (1975). The name is usually misspelled as 'somai'.

Acknowledgements The authors are grateful to the curators of BM, E HAST, K, KYO, P, PPI, TAI, TAIF, TI and TNM for their kind assistance and allowing us to examine the specimens in their care. The kind offer of some specimen materials from TNM for molecular experiments is also deeply appreciated.

\section{REFERENCES}

Alvarez I, Wendel JF. 2003. Ribosomal ITS sequences and plant phylogenetic inference. Molecular Phylogenetics and Evolution 29: 417-434.

Camus A. 1921. Notes sur quelques genres de Graminées. Annales de la Société Linnéenne de Lyon II, 68: 201.

Chen CH, Kuoh CS. 2007. Microstegium japonicum (Miq.) Koidz. as a newly recorded grass to Taiwan. Endemic Species Research 9, 2: 77-80.

Clayton WD, Renvoize SA. 1986. Genera graminum. Kew Bulletin Additional Series 13: 335 . 
Felsenstein J. 1985. Confidence limits on phylogenies: an approach using the bootstrap. Evolution 39: 783-791.

Franchet AR, Savatier PAL. 1876-1878. Enumeratio plantarum in Japonia sponte crescentium 2: 190, 609. Savy, Paris.

Hackel E. 1889. Andropogoneae. In: De Candolle ALPP, Monographiae Phanerogamarum Prodromi 6: 179. Masson, Paris.

Hall TA. 1999. BioEdit: a user-friendly biological sequence alignment editor and analysis program for Windows 95/98/NT. Nucleic Acids Symposium Series 41: 95-98.

Hayata B. 1918. Icones plantarum formosanarum: 74. The Bureau of Forestry, Industries, Government of Formosa, Taihoku.

Hochstetter CF. 1846. Gramineae Juss. In: Von Krauss CFF, Beitrage zur Flora des Cap- und Natallandes. Flora 29: 117.

Honda J. 1930. Monographia Poacearum Japonicarum. Journal of the Faculty of Science, University of Tokyo, Section III, Botany: 405, 407. Tokyo University, Tokyo.

Hsu CC. 1975. Taiwan grasses: 731-734. Taiwan Provincial Education Association, Taipei. (In Chinese.)

Hsu CC. 2000. Microstegium. In: Boufford DE, Hsieh CF, Huang TC, Kuoh CS, Ohasi H, Su HJ (eds), Flora of Taiwan, Vol. 5, 2nd ed.: 562-567. Editorial Committee of the Flora of Taiwan, Department of Botany, National Taiwan University, Taipei.

Kimura M. 1980. A simple method for estimating evolutionary rates of base substitution through comparative studies of nucleotide sequences. Journal of Molecular Evolution 16: 111-120.

Koidzumi G. 1929. Contributiones ad cognitionem florae Asiae orientalis. Botanical Magazine (Tokyo) 43: 394.

Koyama T. 1962. Nomenclatural remarks on some grasses. Journal of Japanese Botany 37: 238.

Koyama T. 1971. Gramineae. In: Walker EH, Journal of Japanese Botany 46: 65.

Koyama T. 1987. Grasses of Japan and its neighboring regions, an identification manual: 427, 516. Kodansha Ltd., Tokyo.

Kress WJ, Wurdack KJ, Zimmer EA, Weigt LA, Janzen DH. 2005. Use of DNA barcodes to identify flowering plants. Proceedings of the National Academy of Sciences 102: 8369-8374.

Kuntze, O. 1891. Revisio generum plantarum: 775. Felix, Leipzig, etc.

Mason-Gamer RJ, Weil CF, Kellogg EA. 1998. Granule-bound starch synthase: structure, function, and phylogenetic utility. Molecular Biology and Evolution 15: 1658-1673.

Mathews S, Spangler RE, Mason-Gamer RJ, Kellogg EA. 2002. Phylogeny of Andropogoneae inferred from phytochrome B, GBSSI, and ndhF. International Journal of Plant Sciences 163: 441-450.

Miquel FAW. 1866a. Annales musei botanici Lugduno-Batavi 2: 290. Van der Post, Amsterdam, etc.

Miquel FAW. 1866b. Prolusio florae japonicae: 178. Van der Post, Amsterdam, etc. [Partially reprint of Miquel 1866a].

Murray MG, Thompson WF. 1980. Rapid isolation of high molecular weight DNA. Nucleic Acids Research 8: 4321-4325.

Nees von Esenbeck CGD. 1836. In: Lindley J, A natural system of botany, ed. 2: 447. Longman et al., London.
Nees von Esenbeck CGD. 1841a. A descriptive catalogue of the Gramineae and Cyperaceae contained in the Indian herbarium of Dr. Royle. Proceedings of the Linnean Society of London 1: 92-93.

Nees von Esenbeck CGD. 1841b. A descriptive catalogue of the Gramineae and Cyperaceae contained in the Indian herbarium of Dr. Royle. Annals and Magazine of Natural History, including Zoology, Botany, and Geology 7: 220. [Partially reprint of Nees von Esenbeck 1841a].

Nei M, Kumar S. 2000. Molecular evolution and phylogenetics. Oxford University Press, New York.

Ohwi J. 1936. Plantae novae japonicae (III). Journal of Japanese Botany 12: 653.

Ohwi J. 1937. Symbolae ad floram Asiae orientalis XV. Acta Phytotaxonomica et Geobotanica 6: 151 .

Ohwi J. 1942. Gramina japonica IV. Acta Phytotaxonomica et Geobotanica 11: $155-156$.

Roberty G. 1960. Monographie systématique des Andropogonées du globe. Boissiera 9: 346, 388-389.

Saito N, Nei M. 1987. The neighbor-joining method: a new method for reconstructing phylogenetic trees. Molecular Biology and Evolution 4: 406-425.

Spangler RE. 2000. Andropogoneae systematics and generic limits in Sorghum. In: Jacobs SWL, Everett J (eds), Grasses, systematics and evolution: 167-170. CSIRO Publishing, Collingwood.

Spangler R, Zaitchik B, Russo E, Kellogg E. 1999. Andropogoneae evolution and generic limits in Sorghum (Poaceae) using ndhF sequences. Systematic Botany 24: 267-281.

Sprengel K. 1815. Plantarum minus cognitarum pugillus 2: 10. Kümmelium, Halle.

Stace CA. 2005. Plant taxonomy and biosystematics - does DNA provide all the answers? Taxon 54: 999-1007.

Steudel EG. 1854. Synopsis plantarum glumacearum 1: 409, 412. Metzler, Stuttgart.

Stoeckle M. 2003. Taxonomy, DNA and the bar code of life. BioScience 53: 2-3.

Swofford DL, Olsen GJ, Waddell PJ, Hillis DM. 1996. Phylogenetic inference. In: Hillis DJ, Moritz C, Mable BK (eds), Molecular systematics, 2nd ed.: 407-514. Sinauer Association, Sunderland, Massachussetts, USA.

Tamura K, Dudley J, Nei M, Kumar S. 2007. MEGA4: Molecular Evolutionary Genetics Analysis (MEGA) software v4.0. Molecular Biology and Evolution 24: 1596-1599.

Trinius CB. 1832. Andropogoneorum genera speciesque. Mémoires de l'Academie Imperiale des Sciences de Saint-Petersbourg. Sixieme Serie. Sciences Mathematiques, Physiques et Naturelles. Seconde Partie: Sciences Naturelles 2: 304, 307.

Tzvelev NN. 1966. Notae de Gramineis florae URSS, 4. Novosti Sistematiki Vysshchikh Rastenii 1966: 15.

Tzvelev NN. 1976. Zlaki SSSR [Grasses of the USSR]. 1st (Russian) ed.: 695. Nauka Press, Leningrad.

Watson L, Dallwitz MJ. 1992. The grass genera of the world: 581-583. Cab International, Wallingford. 